This is the accepted manuscript of the article, which has been published in Horn, S., Lecomte, P. \& Tietze, S. (eds) Managing Multilingual Workplaces : Methodological, Empirical and Pedagogic Perspectives. London: Routledge. Routledge Studies in International Business and the World Economy.

ISBN: 978-1-138-36479-0. http://dx.doi.org/10.4324/9780429431128-6

Translatorial Linguistic Ethnography in Organizations

Kaisa Koskinen

Tampere University 


\section{TRANSLATORIAL LINGUISTIC ETHNOGRAPHY IN ORGANIZATIONS}

\section{Translatorial Linguistic Ethnography in Organizations}

Many if not most contemporary workplaces are multilingual and in numerous ways connected and networked across borders. The linguistic set-ups and communication needs take different shapes, but entirely monolingual work is a rarity in today's connected and globalized societies. Executives are recruited internationally or seconded to expatriate positions, and even if staying home they interact with their global peers and operate between company headquarters and local organizations. These higher echelons of work often operate with a controlled language regime and a combination of local languages and an international prestige language, in today's world often English. In comparison, the most multilingual workplaces may well be found in shop floors and low skills workplaces of Western countries, where people with immigrant background find employment. In these work communities the company language and the national language may be accompanied by a multitude of languages and locally relevant lingua francas.

All these multilingual workplaces are also spaces of translation, with their explicit or implicit language and translation policies (Meylaerts 2011) and their organically grown and habitualized translation cultures (Prunč 2008, p. 24-25). Michael Cronin (2006, p. 68) conceptualizes multilingual, multi-ethnic space as first and foremost a translation space, i.e. a space where translation needs to happen for mutual comprehensibility and where multilingual repertoires meet and mix. Translation, then, needs to be understood in a wide sense of transcultural and interlingual movement of verbalizations (Prunč 2008, p. 19). Translation that takes place in organizational translation spaces is not only the kind executed by professional translators, for complete and final documents, labelled as translations and ordered from the in-house translation department or translation agencies. Translation is much more widespread in the everyday functioning of the organization, and much more fluid and porous. Recurrent orality, as opposed to written translation, adds to its ephemerality. This 


\section{TRANSLATORIAL LINGUISTIC ETHNOGRAPHY IN ORGANIZATIONS}

climate of constant movement between different languages can be called tanslatoriality, and once we start looking we realize that translatoriality is embedded in societal life in most corners of the contemporary, networked world.

These spaces can therefore also be conceptualized as translatorial spaces, a concept derived from Holz-Mänttäri’s concept of translatorial action and signalling a space of translation activity emphasizing actors (Koskinen, 2017). Since the publication of Justa HolzMänttäri's now classic treatise in 1984, translatorial action has, in Translation Studies vocabulary, been used to denote translators' activity that transgresses the boundaries of equivalence-based search for optimal correspondence between two texts. That is, the translation may radically deviate from word-to-word correspondence, and it may also be based on more than one source text. Holz-Mänttäri's research ethos was to empower and raise the status of professional translators. In recent research, her original focus on professional translators has been enlarged to all kinds of translation actors invested in the communication event in various ways, and the attribute 'translatorial' used to signal all kinds of parallel movement from one language to another, whether they are labelled as translation by the actors themselves or not (Koskela, Koskinen, \& Pilke, 2017; Koskinen, 2017).

Organizations operating in more than one language need to develop practices of dealing with the movement from one language to another, i.e. for managing translatoriality. Even in situations where separate translation/interpreting units have been set up, the organizations are sometimes largely unaware of the effects of this movement in their daily activities, brand and image work, customer relations and, finally, economic success. An emerging research agenda in organization studies and international business literature (Piekkari et al., 2013; Piekkari et al., 2014; Chidlov et al., 2014; Tietze et al., 2017; Ciuk \& James, 2015; Ciuk et al., 2018) is beginning to address this under-researched area. For relevant methodology to study translatoriality in organisations, one logical avenue is to turn 


\section{TRANSLATORIAL LINGUISTIC ETHNOGRAPHY IN ORGANIZATIONS}

to Translation Studies, a wide-ranching and multidisciplinary field for researching translation and interpreting. From within the disciplinary perspective of Translation Studies, this chapter aims to support this emerging line of inquiry in two ways: 1) by providing conceptual tools for discussing and describing relevant related features, and 2) by indicating translatorial linguistic ethnography as one potential methodological avenue for future research. To illustrate the possibilities, two case examples of relevant studies within Translation Studies are discussed.

\section{Linguistic ethnography and translatoriality}

\section{Linguistic ethnography}

During its forty odd years of existence, Translation Studies has provided a wealth of new knowledge on fields such as literary, business or audio-visual translation and the many modes of oral interpreting. Foci have varied from social and cultural contexts to agents and actors and to comparative analysis of source and target texts (for an overview see e.g. Munday, 2016). The sustained research focus closest to the current interest in workplace language practices is the branch of researching institutional translation (see Kang, 2009; Koskinen, 2011; Schäffner, 2018) where the workplace practices in various institutional settings have been studied with the help of ethnographic methods. In this chapter, particular emphasis will be given to linguistic ethnography as an avenue for understanding the roles of languages and their interplay in the functioning of organizations, and to translatorial linguistic ethnography (my neologism) in understanding translatoriality in multilingual organisations.

Linguistic ethnography is a largely UK-based line of research born organically around the turn of the millennium from a number of gatherings of like-minded scholars (Linguistic Ethnography Forum, 2004). It is reminiscent of linguistic anthropology practices in the US, and it builds on the foundational work of Frederick Erickson, John Gumperz, Dell Hymes 


\section{TRANSLATORIAL LINGUISTIC ETHNOGRAPHY IN ORGANIZATIONS}

and other classics of interaction research (Shaw, Copland, \& Snell, 2015). Linguistic ethnography is not a set methodology nor a fixed research agenda, but Shaw et al. (ibid.) have identified a number of recurrent themes: 1) interdisciplinarity, 2) topic-oriented approach to ethnography (as opposed to anthropological full scale immersion), 3) use of multiple data sets, 4) an aspiration to improve social life, and 5) combining linguistics with ethnography. The three first ones are rather self-evident in the sense that ethnography typically mobilizes different sources of data and ethnography employed outside anthropology tends to be topicoriented and interdisciplinary. The fourth one is more interesting as it signals an activist bend that is also visible in ethnography as it has been used in Translation Studies. Similar activist traits seem to be far less prominent in organization studies. This research position is not, however, in any way prescribed by the methodology, and may be a consequence of other factors such as researcher personalities. What remains as the defining feature is the fifth and the most obvious one: the dominant role of linguistic data and its detailed analysis within an overall ethnographic framework, linking the micro elements of textual detail to the macro level of organizational practices.

Simply put, linguistic ethnography is a combination of ethnography and linguistic analysis (Shaw, Copland, \& Snell, 2015). Rampton (2007, p. 3) defines linguistic ethnography through these two foundational elements as follows:

1) Its methodology is grounded in ethnography: "meaning takes shape within specific social relations, interactional histories and institutional regimes, produced and construed by agents with expectations and repertoires that have to be grasped ethnographically."

2) The role of language data is crucially important. Linguistic analysis is embedded in the research design, and verbalizations are researched in minute detail: "Meaning is far more than just the 'expression of ideas', and biography, identifications, stance and nuance are extensively signalled in the linguistic and textual fine-grain." 


\section{Repertoires, translatorial encounters and organizational contexts}

In practice, the combination of the over-arching cultural understanding and the microscopic study of textual data in linguistic ethnography allows for many kinds of research designs and a multitude of data sets and foci, ranging from members to situational encounters and institutional contexts.

First, Rampton's (2007, p. 3) long list of elements to observe and analyze in the members category includes

their physical bodies, senses and perceptions; their cultural and semiotic repertoires, and the resources they have at their disposal; their capacities, habitual practices and dispositions; their likes and dislikes, desires, fears, commitments, and personalities; their social status and category memberships.

For the present purposes, I wish to particularly highlight repertoires and resources because of their importance to a translatorially focused linguistic ethnography. In sociolinguistics repertoire is traditionally defined as the variety of languages used by the members of a particular speech community, but in contemporary research and in this context it is also intended as a term for individual linguistic competence. What languages the members have at their disposal, to what level and in which variant or accent (i.e. their linguistic resources), and how skilfully they can employ various translatorial strategies (i.e. their translatorial repertoires) will crucially affect their position at the workplace and their possibilities for taking translatorial agency and using it for their purposes (see e.g. Chew, 2005; Piekkari et al, in press). Habitual language and translation practices, and dispositions towards them, are also significant. Particularly in the absence of a robust translation policy, members of the organiation will find workarounds and ways of organically sorting out their translatorial needs (Piekkari et al., 2013). 


\section{TRANSLATORIAL LINGUISTIC ETHNOGRAPHY IN ORGANIZATIONS}

Second, Rampton's (2007, p. 3) listing of elements to observe in the situational encounters that members and texts - and, by extension, translatorial practices - are embedded in, is equally extensive:

the events, genres and types of activity in which people, texts and objects interact together; actions, sequences of actions and the use of semiotic materials (signs, language, texts, media); inferencing, interpretation and the efforts of participants to understand or influence each other; the physical arrangement of the participants and the material setting; origins, outcomes and wider links - how signs, actions and encounters fit with interactional and institutional processes over longer and broader stretches of time and space.

In this kind of ethnography the "use of semiotic materials" is the centre of attention. In ethnography, a repeated guideline for fieldwork is "follow the actors". In linguistic ethnography it is equally important to follow the texts as the participants take efforts to model and mould them, also through translation processes, for the various organizational purposes, and texts travel in various forms of distribution from one member, department, organisation and sometimes country to another. It is therefore important to ask what are the texts used for, how and by whom: who writes or speaks, for which purposes and to influence who and how; who distributes and through which channels and media; who is targeted and expected to read and who is excluded (because of limited access or lacking language resources); who will take the role of explaining to others and how and why; who translates, how and for whom; who revises and reinterprets and for which purposes; who stores and archives and is this organizational memory referred to. And so on.

The third layer of contextualization consists of more or less durable institutions, groups and communities of practice, and research is expected to look into how "institutions shape, sustain and get reproduced through texts, objects, media, genres and practices" as well as how they produce, control and manage "persons, resources, discourses, representations, 


\section{TRANSLATORIAL LINGUISTIC ETHNOGRAPHY IN ORGANIZATIONS}

ideologies, spaces" and so forth (Rampton, 2007, p. 3). Many modern organizations and institutions are entirely text-based in that their out-put is entirely written or spoken material. They are talked into being (Heritage, 1984, p. 290), written into being, and in a multilingual and translatorial world they are also translated into being (Koskinen, 2008, p. 3). The texts that workers produce at work create the work.

The three layers are interlinked: "with varying degrees of friction and slippage, repertoires get used and developed in encounters, encounters enact institutions, and institutions produce and regulate persons and their repertoires through the regimentation of

encounters" (Rampton, 2007, p. 3). Rampton (ibid.) labels the three levels as 'persons', 'encounters' and 'institutions'. This is not too far removed from what was developed within Translation Studies for the purposes of an ethnography of translation work at the European Commission (Koskinen, 2008) around the same time. With no explicit reference to linguistic ethnography, the study employs a similar architecture, with three levels, but whereas the linguistic ethnography of Rampton tacitly prioritizes spoken encounters, Koskinen (2008) operates on written texts, and the most micro-level inspection is that of a gradual drafting of a Commission document in English and the gradual gestation of its translation into Finnish through the various intermittent text versions and revisions. The "meso-level" is that of persons - the professional translators and the community of practice they have in the Finnish translation unit (I will return to this case in section 4.1 below).

\section{Agents of translation}

In a manner typical for most Translation Studies research, Koskinen's research (2008) focuses on professional translators, and also the analysis of the translations is employed to support the aim of understanding their workplace culture. Ethnography is about people in their social and cultural environment, and also linguistic ethnography focuses on people, even if also through the lens of the texts they produce. The power positions of the various actors 


\section{TRANSLATORIAL LINGUISTIC ETHNOGRAPHY IN ORGANIZATIONS}

and their aims and motivations (their skopoi) play a significant role in defining how the translation events will unfold. Holz-Mänttäri (1984; see also Koskinen, 2017) identifies six key roles of a translatorial event as follows:

a) the initiator, who needs a translation for a purpose

b) the client, who commissions translatorial action

c) the source-text producer

d) the translator

e) the user of translation (i.e. the one who needs the translation to accomplish a task)

f) the addressee (i.e. the end-user of the translation)

In organizations these roles can be played by many actors, and people may alternate in different roles, resulting in different set-ups and hierarchies depending on language, text type and other situational factors. These roles may be quite distinct in cases when full translation of an existing text is requested from a professional translator, but in the case of more fluid translatoriality, things can be much more fuzzy. As Koskela et al.'s (2017) data indicates, role-taking may be quite subtle and even subconscious, but it is also dependent on the institutional status and position of different actors (see section 4.2 below). Not everybody can push themselves forward as translators and not everybody is in the position of demanding translatoriality even when in need. Arguably, this latter form of translatoriality, the one without professional translators and interpreters, is the more common one, in the world at large and in organizations. In workplaces, various translatorial activities are constantly carried out by translators who are doing it alongside their other occupational tasks, not necessarily labelling them translating or even recognizing their translatorial nature (which can be a challenge for interview studies as the full extent of translatoriality may be difficult to capture through members' self-reports). These actors are professionals and translators but not 


\section{TRANSLATORIAL LINGUISTIC ETHNOGRAPHY IN ORGANIZATIONS}

professional translators. In Translation Studies this group has recently been labelled as paraprofessional translators (Koskela et al. 2017), to differentiate them from both professional translators and non-professional translation that takes place entirely outside the occupational and salaried realm.

This group - the consultants, the CEOs and other paraprofessional translators in organizations - are an interesting sub-group of boundary spanners (see e.g. Williams, 2002) spanning interlingual boundaries as they reverbalize and set in motion meanings that circulate across languages. They are also a theoretically interesting group from the perspective of Translation Studies because their translation practice is unconstrained by the professional norms nor controlled by codes of conduct, professional ideologies of good translation or inbuilt understandings of translator habitus. Some evidence indicate that they might be willing and able to exert more agency and resort to bolder translation strategies than professional translators (Buzelin 2014), thus pushing the boundaries of translational behaviour. This is why understanding them, and their translatorial behaviour, is highly relevant also for Translation Studies.

\section{From linguistic ethnography to translatorial linguistic ethnography}

It needs to be noted that linguistic ethnography is not a label often used within Translation Studies whereas ethnography in itself has become a trendy method. Linguistic ethnography was first introduced into Translation Studies by Peter Flynn (2006) in his PhD on literary translation and Moira Inghilleri (2006) in the context of her ethnographic research of asylum interpreting, and more recently by Wine Tesseur (2014) in her PhD research on translation practices and policies in Amnesty International. This is not a strong lineage of previous research yet, but many more works that combine ethnography with translation and interpreting topics could easily be placed under this umbrella term, although it has not been in active use (Tesseur, 2017). For example Koskinen (2008, p. 36), one of the first to 


\section{TRANSLATORIAL LINGUISTIC ETHNOGRAPHY IN ORGANIZATIONS}

introduce ethnography into the study of translation practices, only mentions it in passing. One reason may be that it is not yet, and even less so a decade ago, an established research tradition in sociolinguistics where it originates from, but rather still an emerging field (Rampton, 2007; Shaw, Copland, \& Snell, 2015). It also needs to be noted than in linguistic ethnographies conducted outside Translation Studies, translation issues are rarely topicalized. Still, what has been done in this area seems particularly well adapted to complement the research this far conducted on organizations and their translatoriality. The methodology of linguistic ethnography promises to fill a gap in existing research because of its consistent foregrounding and close attention to languages as they manifest in the micro features of language use the everyday life.

The crucial question is what adding the linguistic, and more specifically translatorial, layer to the research design can add. Is the added value worth the effort for those interested in organizational life and not in the subtleties of linguistic structures? In my opinion, yes. In the case of written translatoriality, where the "same" text exists in more than one language, the resulting paper trail of transformations available for a comparative analysis allows for pinpointing interpretive challenges and ideological touchstones. The translatorial practices themselves are revealing in terms of interactional and institutional hierarchies and power structures: Which languages are selected, which are not? Are the versions produced simultaneously or is there a temporal difference that signals prioritization? Are all versions equally official or are some groups only served by accidental or voluntary linguistic support from their co-workers similar to what Svetlana Probirskaja (2017) has labelled linguistic first aid? Are there institutionalized translation processes, regulatory guidelines and nominated translators or is the practice irregular, non-resourced and uncontrolled? Oral translatoriality leaves less traces unless multilingual oral interactions are recorded for research purposes, but if that data is available (and often in contemporary ethnographies it may be the case), the 


\section{TRANSLATORIAL LINGUISTIC ETHNOGRAPHY IN ORGANIZATIONS}

minutiae of multilingual interaction will likely reveal a rich pool of evidence for example on the usability of personal linguistic repertoires in controlling interpretations and on inclusion and exclusion via translation strategies (e.g. by providing swift summary translation to keep all participants up to speed about an on-going discussion, see Koskela et al., 2017).

Importantly, the micro data of everyday action allows for a triangulation of data: interview study, the currently dominant method for understanding translation work in organizations in International Business (see section 3 below), offers possibilities for understanding the ideologies, values, aims and targets of optimal performance; documented translatorial behaviour explains what goes on in practice. In any human action, words and deeds form a complex dialectical relationship. The ensuing triangulation of different data sets is unlikely to result in simply validating one another in any straightforward manner. Rather, it will complexify and relativize the findings:

In this case [translating in the European Commission], the question of triangulation is confused: on the one hand --- the different sets of data and different methods tell the same story; on the other hand, the story they all repeat is a story of incongruence, of a continuous battle between the readers and the institution.

The benefit of mixing different kinds of data and viewpoints is in understanding their tensions and interrelatedness. The translators' own views of their roles are seasoned by a look at the official documents which both ignore them completely and offer them a potentially significant role. Similarly, translators' laments of not being able to take the readers into account are balanced by an analysis of the case translation where the translator obviously does a lot precisely to enhance readability. (Koskinen, 2008, p. 150).

Language, and by extension translation, is a complex tool for human interaction, but its social nature is not necessarily fully obvious to scholars in other fields. It may therefore seem unnecessary to pay attention to language issues in one's object of study, or in one's research design for that matter (multilingual workplaces will often place demands on 


\section{TRANSLATORIAL LINGUISTIC ETHNOGRAPHY IN ORGANIZATIONS}

language skills of the research teams, and interpreters and fixers are often used to facilitate fieldwork without too much reflexion on how this may affect the results; See Tietze \& Dick, 2013). Incorporating textual data into the research design may therefore appear a pointless exercise of nitty-gritty grammatical analysis. Research into translation in institutions within an explicit or implicit linguistic ethnography framework consistently agrees in seeing linguistic data as an element of micro analysis, but it equally consistently argues that observations on linguistic features and source-target comparisons are not only interesting for those who are into linguistic structures. On the contrary, "language and the social world are mutually shaping", and analyzing situated language use can provide "both fundamental and distinctive insights into the mechanisms and dynamics of social and cultural production in everyday activity" (Linguistic Ethnography Forum, 2004, p. 2). Linguistic ethnography is not concerned with the micro-level linguistic features of themselves, but with how the language use in interaction is socially and institutionally framed (Inghilleri, 2006, p. 57). Furthermore, the entire disciplinary understanding of translatorial action is socio-culturally oriented. As opposed to lay expectations of mechanical sameness between source and target texts, shifts (of meaning, expression, connotation and so forth) are in Translation Studies considered a universal feature of translation (Toury, 2012). These shifts provide openings into the social and institutional framing of translatoriality (see Koskinen, 2008, Ch. 6). A close comparative analysis of the shifts of meaning in situated language use, as documented in the different language versions, functions as the looking glass of microspection that allows us to have whole worlds reflected in it (Cronin, 2012, p. 1).

\section{Researching translatoriality in organizations}

In the study of multinationals and global businesses, social and cultural differences have been identified as a significant boundary to be crossed, and organizatory boundary spanners and "translators" who adapt and localize incoming practices, have been a target of 


\section{TRANSLATORIAL LINGUISTIC ETHNOGRAPHY IN ORGANIZATIONS}

extensive research. it is much more rare to find studies that would take the linguistic understanding of translation seriously and engage directly with textual translatorial data, either written translations or oral interpretations. This situation is now changing, as many fields of enquiry are witnessing a "translation turn" (Evans 2018), beginning to pay attention to and problematize the translatorial practices encountered in the contexts studied, and turning to Translation Studies for support (Piekkari et al., in press).

A growing body of research into organisational life contains interlingual translations as a core element of analysis. In this current organization studies literature on translation in multilingual organisations, the levels of people and institutional context are typically covered. Researchers looking into translation engage in fieldwork observations and conduct extensive interviews on actors identified as central for translation work, be they outside consultants (Tietze et al., 2017), the local CEO (Logeman \& Piekkari, 2015), or local branch middle management (Ciuk \& James, 2015; Ciuk et al., 2018). Shop floor translatoriality is less prominent in international business research, but it might indeed prove interesting to follow the translations down all organisational layers and to also include the reception end in the analysis. A recent study of the language policy of the global manufacturer Wärtsilä located in Finland indicates that some hick-ups in the transfer of practices may well be caused by insufficient translatoriality between ladders of the organisational hierarchy. Here's a quote from a factory worker (Malkamäki \& Herberts, 2014, p. 53; my translation):

Well I did not understand all of it myself, let alone those whose language proficiency is even lower, and they were quite confused. Well, afterwards maybe something was sent in writing about what had been discussed for those who do not understand at all, something has to come, like, someone then translated the main points.

The case studies mentioned above are, for the time being, exceptional in their disciplinary context in their direct engagement with the linguistic level of analysis of 


\section{TRANSLATORIAL LINGUISTIC ETHNOGRAPHY IN ORGANIZATIONS}

translatoriality. Still, from the perspective of a Translation Studies scholar it seems that to fully benefit from the explanatory potential of translatorial data they could still be pushed further in the direction of translatorial linguistic ethnography. I suggest three areas of development:

1. Deeper engagement with translation data: a comparative analysis of source and target texts from the viewpoint of shifts and translation strategies would provide tangible evidence of power relations, politeness issues, taboos, cultural differences and so on.

2. Integrating Analysis: An integrated analysis of the three levels discussed in the above section, comparing and contrasting textual data with translatorial discourses and statements (typically obtained by interviews) and with the institutional aims and constraints. The way in which Ciuk et al. (2018) use skopos (a term in Translation Studies for the purposes of the translation) as one such connector between textual evidence and higher level aims is a good indicator of the potential for bringing Translation Studies concepts and theories in contact with the disciplinary aims of Organization Studies.

3. Following the translation: Current research provides snapshots of translation but does not necessarily retract back to the origin of the translation trail nor follow it through during its full organizational extent, differentiating between a translation act (the process of producing the translation) and the translation event (Toury 2012) from its gestation in the form of a perceived need by someone up to its reception and its social afterlife. The diagram by Piekkari et al. (2014, p. 30) provides a good model for an organizational analysis of a translation event.

Integrative research designs combining Translation Studies and Organization Studies viewpoints would naturally also be enriching for Translation Studies. Although the explanatory power of context has long been recognized as crucially important in Translation Studies, the disciplinary tradition tilts towards textual analysis, and translation scholars would 


\section{TRANSLATORIAL LINGUISTIC ETHNOGRAPHY IN ORGANIZATIONS}

benefit greatly from a more fine-tuned organizational understanding. Although fieldwork methods are gaining popularity in Translation Studies, research skills in this area are not widely taught, making fieldwork a learning experience for most researchers. Even more importantly, the theoretical conceptualizations of organizational issues are not as robust as they might be if an interdisciplinary team was working together (for an example of an extensive textual analysis of translation in a MNC with a clear opening for input form the OS side see Brunelière, 2017).

A closer look at language issues and translatorial movements between languages provides documented evidence of the political processes at play. Looking into challenges of translatability of the concept of social inclusion into Hungarian within the context of policy transfer from the European Union to Hungary within a framework that closely resembles translatorial linguistic ethnography, Noémi Lendvai (2015, p. 142) underlines the importance of acknowledging the "spaces beneath the surfaces of the 'common' the 'shared', the 'same' language and the breakdown of the supposed linear assembly-line process of policy transfer and policy learning". She defines interlingual translation not only as a matter of language but as "a broader process of policy production and assemblage". The struggles for meaning during "awkward encounters" of languages, language re-engineering by strategic backtranslation, and the productive lacunae in languages allow her to identify translation as an immensely important process: "translating across languages not only transmits, transfers and transplants but also makes, crafts and alters, policies" (p. 154). Similar emphasis of translation as a tool for micro-political soft power can be found in Logemann and Piekkari, 2015; Tietze et al., 2017 and Ciuk et al., 2018, in Organization Studies/International Business literature, and also in Inghilleri, 2006, Koskinen, 2008, and Tesseur, 2017 in Translation Studies. Translation is seen as "a site of struggle occupied by many actors with different 


\section{TRANSLATORIAL LINGUISTIC ETHNOGRAPHY IN ORGANIZATIONS}

power positions bound to different institutional ideologies" (Tesseur, 2017, p. 18). In research, it is overlooked and taken for granted at the researcher's risk and peril.

\section{Two examples of researching translatoriality in organizations}

The above sections have argued for a more intense engagement with translatorial data in studying multilingualism at work from a meta-level perspective. In this section I aim to show what kinds of findings one can gain from paying attention to the linguistic detail and the shifts therein in the movement from one language to another. I have selected two cases at two extremes of the scale between global and local perspectives. First, I return to the case of the European Union that has already come up a number of times in the discussion above. Drawing on a number of different studies, both my own and by others, I aim to highlight some general translatorial factors that often come to play when policies and practices are moved across borders, and therefore also across linguistic and cultural boundaries. The second case is much more narrow in scope. It is based on the research I conducted with two colleagues (Koskela et al., 2017), and it provides a snapshot of organisational everyday bilingual practices, and the translatorial strategies used in oral discourse. The purpose of the latter case is to give ideas of how the more fuzzy areas of paraprofessional translatoriality can be addressed in research. The context of case 2 is one typical of most organisations: a meeting.

\section{Case 1. Translating the European Union}

Among supranational institutions the European Union is unique in both its relentless multilingualism and its penetration into the national spheres of its member states. The policies and practices aim at harmonizing the European regulatory and ideological framework in many domains of life. Hence also the need for many languages: to succeed in getting the ideologies and pragmatic applications accepted and adopted in the various local contexts, the European Union needs to make itself understood and accepted, and speaking the local 


\section{TRANSLATORIAL LINGUISTIC ETHNOGRAPHY IN ORGANIZATIONS}

language is a crucial element in this project (Koskinen, 2008, Ch. 4). In practice, this is accomplished by running the biggest translation and interpreting services in the world. The European Union therefore functions well to highlight a number of relevant issues in organizational translatoriality in multinational organizations.

Acceptability (Toury, 2012) is one of the key concepts in Translation Studies, reflecting a strong target-orientedness at the heart of the discipline. In the EU context, at stake is not only the acceptability of the translation but also the acceptability of the entire institutional system through translations. Translation strategies have not always been successful, as testified by a long trail of complaints about unclear, foggy, and alienating reading experiences both in the press and in research literature. It is not entirely by coincidence that Lendvai (2015, p. 154) states a personal sense of alienation as the origin of her research interest into how European texts travel in translation, referring back to a similar origin of Koskinen's research.

The constant battle between readability (the target) and institutional constraints (the source) is a consistent finding in Koskinen (2008), through all data sets from the institution's own communication strategies to translator's talk and to the actual translation strategies, and the translations are indeed one site of that struggle. The necessity to strike a balance between staying close to the source text form, content and style and matching the new text to the target context is a foundational, and unresolvable, problem of translation, and therefore also one that will unavoidably be at play in organizational contexts. The line between localizing and telling local lies (Logemann \& Piekkari, 2015) is blurry, and successful translatoriality often requires a degree of free reinterpretation (see e.g. Ciuk \& James, 2015). Very literal rerendering of the original wording is often clumsy at best and incomprehensible at worst (Koskinen, 2008, p 133). To add complexity, also extremely localizing translation strategies can cause alienation in the readers. This is what also happened in the early Finnish EU 


\section{TRANSLATORIAL LINGUISTIC ETHNOGRAPHY IN ORGANIZATIONS}

translations that suffered from an "overdomestication" tendency through an excessive avoidance of loan words, for example by translating the word 'report' as 'kertomus' ("story") rather than using the more common localized loan word 'raportti', or having 'yhteensovittaa' (“to fit together") instead of 'koordinoida' to translate 'to coordinate' (Koskinen, 2012; cf. Koskinen, 2008, p. 134).

A recurrent translatorial challenge is cause by realia, i.e. linguistic expressions for elements in the social and cultural life that are specific to one context and hence not verbalized in the other. Much of EU terminology has been resistant to translation because the target culture lacks a similar concept. Lendvai (2015) reports the difficulties of translating social inclusion into Hungarian. The situation is quite similar to the "discursive void" encountered in translating Western business terms into the post-socialist Slovak reality (Tietze et al., 2017). Since the European Union is a political institution, its discourse is also often intentionally fuzzy (and therefore difficult to translate) - Lendvai (2015, p. 145) calls it "fiction-writing" - and its terminology is sometimes unstable because of the rapidly evolving political scene around the terms (see Marani, 2018, for an analysis of the migration of the term 'migration' in EU discourse). Identifying these contested terms and words that resist easy translation can be used to highlight ideological, social and cultural boundaries, and analysing their successful and failed translations can be revealing in terms of pinpointing the nature of that boundary.

Source and target-oriented translation strategies and solutions for realia translation are elements translators can consciously work on, and professional translators are trained to find workable tactics for getting around them. These have been called optional shifts in translation theory (Vinay \& Darbelnet, 1958). Translation also entails obligatory shifts that result from the differences between language systems and reflect on what a particular language either can or has to make explicit. For example, in English you are expected to signal the gender of the 


\section{TRANSLATORIAL LINGUISTIC ETHNOGRAPHY IN ORGANIZATIONS}

person in the third person pronoun; in my native language Finnish we only have pronoun ('hän'). These shifts, too, can affect the target text reception, sometimes significantly. For example, the different systems of modal verbs in English and Finnish, and the standardized practice of translating them, were found to lead to softening of the degree of directiveness in EU communication (Koskinen, 2000, p. 142-144), and the variation of idiomaticity in metaphors lead to a loss of a connotation to 'heart', and hence reduced affectivity, in other language versions than English (ibid. p. 137).

\subsection{Case 2. Translation practices in a bilingual formal meeting}

EU translation is a massive undertaking, employing thousands of in-house and freelance translators and interpreters. But organisational life also contains an equally massive amount of everyday translatoriality that often goes unnoticed, by management, researchers and participants alike. In the article by Koskela, Koskinen, and Pilke (2017), the researchers zoom into the micro level of oral translatoriality within a bilingual formal meeting where no professional translating or interpreting was provided. The fine-grained analysis of the turns, and a consensus-based matching of content to define the degree and kind of translatoriality reveals a number of elements. For example, it shows how extensively translatoriality is being used to forward the aims of the meeting and how flexibly different translation strategies are brought to play. Summary translation, i.e. condensing the gist of the turn in another language, in particular, appears an efficient and time-saving method of keeping everyone up to speed. Below, the expert's presentation of an issue in Swedish activates the chair to engage in summarizing to make sure also the Finnish-speaking participants are up to speed, thus safeguarding inclusion of all members. However, he only provides the essentials, cutting the length of the turn to less than one half:

Expert: Jo, ordförande, det här är ett projekt som det här baserar sig på att vi ska få en matbutik, en market där och läget är ju på det viset nuförtiden att det här våra 


\section{TRANSLATORIAL LINGUISTIC ETHNOGRAPHY IN ORGANIZATIONS}

investeringspengar har strukits ner till noll, så vi har inte möjlighet att börja med sådana här projekt alls mera utan den här finansieringen måste sökas på andra håll. Prisma öppnar en ny stor market, men som alstrar mycket trafik, så det måste göras en rondell vid bland annat för att få det här att löpa, trafiken, och de här planerna är klara och kostnadskalkylen är (168000 euro). Finansieringen är sådan att kommunen betalar hälften och ELY pengarna då andra hälften.

Chair: Elikkä tää on kaupan liikekeskuksen liikennejärjestelyjen turvaamiseksi ja Luodon keskuksen kehittämisen turvaamiseksi, niin nämä liikennejärjestelyt, ja rahojen vähyys niin johtaa siihen, että tällaista aluekehittämisrahaakin on käytettävä tällaisiin kohteisiin.

[ Expert: Yes, chair, this is a project that concerns a grocery shop, a super market we will get, and the situation today is that since the money for investments has been cut down to zero, so we cannot invest in projects like this without getting financing somewhere else. Prisma will open a large supermarket that will bring about a lot of traffic which is why we need a roundabout in order to get the traffic going, and these plans are ready and the cost estimate is 168000 euro. The financing is such that the municipality will pay half and ELY money the other half.

Chair: So this concerns securing the traffic arrangements of a commercial centre and development of the centre of Luoto, these traffic arrangements, and the lack of money leads to the need of using regional development money for this type of purposes.]

It also becomes evident in the article that formal contexts endow some participants with more translatorial agency than others. In the context of a formal meeting, the chair plays a key role, and having a chair person willing and able to perform translatorially can significantly enhance democratic language use and inclusion of all. The data was collected from a habitually bilingual meeting, and it shows how the chair's performance is dominated by bilingual translatorial turns, both in the form of self-translation and in translating the turns of other participants, showing the chair to be a crucially important role for supporting equal participation and community-building through translation. 


\section{TRANSLATORIAL LINGUISTIC ETHNOGRAPHY IN ORGANIZATIONS}

Methodologically, the article by Koskela et al. describes how naturally occurring speech data can be mapped and classified according to translatorially relevant categories that can be used to create a typology of translation practices and a classification of actor roles. In the absence of professional translators, questions such as who is in a position to demand translation and for whom, and who takes on the role of the translator, are not clear-cut and can be used to identify organizational key actors who engage in translatorial boundary spanning.

\section{Conclusions}

Even among those interested in languages and multilingualism, interlingual translation may sometimes be overlooked as a technicality, not interesting as such. My aim in this chapter has been to show that this is not the case. On the contrary! Translation - in particular the challenges of simple equivalence and the resulting discursive voids - makes visible and highlights the crossing of cultural boundaries, and the organization of translation practices offers a window to the language ideologies, power structures, hierarchies and cultural affiliations in and between organizations and stakeholder groups.

This chapter has forwarded a particular research agenda that combines ethnographic fieldwork and interview data with a close analysis of linguistic data from a translatorial perspective, i.e. translatorial linguistic ethnography. It was argued that multilingual workplaces are full of translatoriality, not only in the form of professional translation and interpreting, but also - and more often - in more ephemeral and ever-present forms of everyday movement between languages both in the form of self-translation and in jumping in to take the role of the translator as the need arises, in addition to one's other workplace roles and occupational tasks. This legion of paraprofessional translators in organizations engage in translatorial boundary spanning. Their activities leave a paper trail of values, attitudes, and ideologies of cultural mediation, documented in their translations and available for 


\section{TRANSLATORIAL LINGUISTIC ETHNOGRAPHY IN ORGANIZATIONS}

researchers through a comparative analysis of source and target texts. Following these translations, and recordings of oral translation practices, provides avenues for researchers interested in studying multilingual workplaces. 
TRANSLATORIAL LINGUISTIC ETHNOGRAPHY IN ORGANIZATIONS

\section{References}

Brunelière, J.F. (2017). Business and Translation as Power Games. The automotive industry in Brazil. Cadernos de traduçao, 37(3), 185-213.

Buzelin, H. (2014). How devoted can translators be? Revisiting the subservience hypothesis. Target, 26, 63-97.

Chew, K.-S. (2005). An investigation of the English language skills used by new entrants in banks in Hong Kong. English for Special Purposes, 24, 423-443.

Chidlow, A., Plakoyiannaki, E., \& Welch, C. (2014). Translation in cross-language international business research: Beyond equivalence. Journal of International Business Studies,45(5), 562-582.

Ciuk, S., \& James, P. (2015). Interlingual translation and transfer of value-infused practices: An in-depth qualitative exploration. Management Learning, 46, 565-581.

Ciuk, S., James, P., \& Sliwa, M. (2018). Micropolitical dynamics of interlingual translation processes in an MNC subsidiary. British Journal of Management. DOI:10.1111/14678551.12323

Cronin, M. (2006). Translation and Identity. London and New York: Routledge.

Cronin, M. (2012). The Expanding World. Towards a Politics of Microspection. Wintchester, UK: Zero Books.

Evans, L. (2018). Language, translation and accounting: towards a critical research agenda, Accounting, Auditing \& Accountability Journal, 31(7), 1844-1873, https://doi.org/10.1108/AAAJ-08-2017-3055

Flynn, P. (2006). A linguistic ethnography of literary translation: Irish poems and Dutchspeaking translators. Unpublished $\mathrm{PhD}$ thesis. Ghent: Ghent University.

Heritage, J. (1984). Garfinkel and ethnomethodology. Cambridge: John Wiley \& Sons. 


\section{TRANSLATORIAL LINGUISTIC ETHNOGRAPHY IN ORGANIZATIONS}

Holz-Mänttäri, J. (1984). Translatorisches Handeln. Theorie und Methode. Annales Academia Scientiarum Fennicae B 226. Helsinki: Helsingin tiedeakatemia.

Inghilleri, M. (2006). Macro social theory, linguistic ethnography and interpreting research. Lingustica Antwerpiensia. Themes in Translation Studies, 5, 57-68.

Kang, J.-H. (2009). Institutional translation. In M. Baker, \& G. Saldanha (Eds.), The Routledge encyclopedia of translation studies (pp. 41-145). Abingdon and New York: Routledge.

Koskela, M., Koskinen. K., \& Pilke, N. (2017). Bilingual formal meeting as a context of translatoriality. Target, 29(3), 464-485.

Koskinen, K. (2008). Translating Institutions: An Ethnographic Study of EU Translation. Manchester, U.K.: St. Jerome.

Koskinen, K. (2011). Institutional translation. In Y .Gambier, \& L. van Doorslaer (Eds.), Handbook of translation studies Vol II (pp. 54-60). John Benjamins Publishing Company.

Koskinen, K. (2012). Domestication, foreignization and the modulation of affect. In edHannu M. Kemppanen, M. Jänis, \& A. Belikova (Eds.), Domestication and foreignization in translation studies (pp. 13-32). Berlin: Frank\& Timme.

Koskinen, K. (2017). Translatorial Action in non-professional translation communities: The Tampere city council in 1875. In K. Taivalkoski-Shilov, L. Tiittula, \& M. Koponen (Eds.), Communities of Translation and Interpreting (Vita Traductiva) (pp. 37-61). Montreal: Éditions québécoises de l'oeuvre.

Lendvai, N. (2015). Soft governance, policy fictions and translation zones. European policy spaces and their making. In J. Clarke, D. Bainton, N. Lendvai, \& P. Stubbs (Eds.), Making policy move: Towards a politics of translation and assemblage (pp. 131-156), Bristol and Chicago: Polity Press. 


\section{TRANSLATORIAL LINGUISTIC ETHNOGRAPHY IN ORGANIZATIONS}

Linguistic Ethnography Forum (2004). UK Linguistic Ethnography: A Discussion Paper. Coordinating Committee. UK Linguistic Ethnography Forum 1. December 2004. Retrieved from https://www.lancaster.ac.uk/fss/organisations/lingethn/documents/discussion_paper_j an_05.pdf

Logemann, M., \& Piekkari, R. (2015). Localise or local lies? The power of language and translation in the multinational corporation. Critical Perspectives on International Business, 11, 30-53.

Malkamäki, A., \& Herberts, K. (2014). Case Wärtsilä: Flerspråkighet $i$ arbetssituationer/Monikielisyys työtilanteissa/Multilingualism in work situations. Vaasan yliopiston julkaisuja, selvityksiä ja raportteja 194. Vaasa: Vaasan yliopisto.

Marani, J. (2018). Migration in Translation: the role of terminology and transediting in shaping the crisis in EU Institutions. PhD. Verona: University of Verona.

Meylaerts, R. (2011). Translation policy. In Y. Gambier, \& L. van Doorslaer (Eds.) Handbook of translation studies 2 (pp. 163-168). Amsterdam, Philadelphia, Pennsylvania: John Benjamins.

Munday, J. (2016). Introducing translation studies. 4th edition. London and New York: Routledge.

Piekkari, Rebecca, Susanne Tietze \& Kaisa Koskinen (accepted). Metaphorical and Interlingual Translation in Moving Organizational Practices Across Languages. Organization Studies.

Piekkari, R., Welch, D.E., Welch, L.S., Peltonen, J.-P., \& Vesa, T (2013). Translation behaviour: An exploratory study within a service multinational. International Business Review, 22(5), 771-783. 


\section{TRANSLATORIAL LINGUISTIC ETHNOGRAPHY IN ORGANIZATIONS}

Piekkari, R., Welch, D.E., \& Welch, L.S. (2014). Language in international business. The multilingual reality of global business expansion. Cheltenham \& Northampton: Edward Elgar.

Probirskaja, S. (2017). Does anybody here speak Finnish? Linguistic first aid and emerging translational spaces on the Finnish-Russian Allegro train. Translation Studies, 10(3), 231-246.

Prunč, E. (2008). Zur Konstruktion von Translationskulturen. In L. Schippel (Ed.) Translationskultur - ein innovatives und produktives Konzept (pp. 19-42). Berlin: Frank \& Timme.

Rampton, B. (2007). Linguistic ethnography and the study of identities. Working Papers in Urban Language \& Literacies 43. London: King's College London.

Tesseur W. (2014). Transformation through translation: Translation policies at amnesty international. PhD. Birmingham: Aston University.

Tesseur, W. (2017). Incorporating translation into sociolinguistic research: Translation policy in an international non-governmental organisation. Journal of Sociolinguistics, 21(5), 629-649.

Tietze, S., \& Dick, P. (2013). The victorious English language: Hegemonic practices in the management academy. Journal of Management Inquiry, 22(1), 122-134.

Tietze, S., Tansley, C., \& Helienek, E. (2017). The translator as agent in talent management knowledge transfer. International Journal of Cross Cultural Management, 17, 151169.

Toury, G. (2012). Descriptive translation studies - and beyond: Revised edition. Benjamins Translation Library, 100. Amsterdam: John Benjamins Publishing Company.

Vinay, J.-P., \& Darbelnet, J. (1958). Stylistique comparée du français et de l'anglais. Méthode de traduction. Paris: Didier / Montreal: Beauchemin. 


\section{TRANSLATORIAL LINGUISTIC ETHNOGRAPHY IN ORGANIZATIONS}

Williams, P. (2002). The competent boundary spanner. Public Administration, 80, 103-124.

Schäffner, C. (2018). Translation and institutions. In J.Evans, \& F. Fernandez (Eds.), Routledge handbook of translation and politics. London and New York: Routledge. pp. 204-220.

Shaw S. E., Copland F., \& Snell J. (2015). An introduction to linguistic ethnography: interdisciplinary explorations. In Snell, J. ,Shaw, S.E. and Copland, F. (Eds.), Linguistic ethnography: Interdisciplinary explorations. Basingstoke: Palgrave Macmillan. pp. 1-13. 